$\xi=$

\title{
Selection of Contractor: a Flexible Performance-Based Approach
}

\author{
Nurshikin Mohamad Shukery ${ }^{1 *}$, Roslan Amirudin ${ }^{2}$, Nafisah Abdul Rahiman $^{3}$, Hamizah Liyana Tajul Ariffin ${ }^{4}$, \\ Syamsul Hendra Mahmud \\ 1,2,3,4,5 Department of Quantity Surveying, Faculty of Built Environment, Universiti Teknologi Malaysia \\ *Corresponding author E-mail: b-nurshikin@utm.my
}

\begin{abstract}
Contractors are the main players in construction industry. Appropriate selection of contractor is crucial in determining the future performance of a project in any case. Sometimes this selection procedure is performed without proper consideration and deliberate methodology that it merits, thus bringing negative outcomes. This paper proposes a performance-based contractor selection approach that will empower the utilization of expert's experience and data. A flexible performance-based contractor selection system is proposed to bolster this decision-making process. To characterize and design the system, semi structured interviews and questionnaire surveys were led within public sector concentrating on the way that the selection process is carried out in practice and the evaluation connected with it. A prototype of a Flexible Performance-Based Contractor Selection System (FPCSS) was developed by using Analytical Hierarchy Process (AHP) method. The system is validated by construction industry professionals in public sector. As a conclusion, the FPCSS is a significant tool for contractor selection, by helping organizations to select a competent contractor and decrease the subjectivity of the decisionmaking process. The advantage as gave by the system favours a reliable indicator to predict performance of construction project by selecting a contractor based on his best performance.
\end{abstract}

Keywords: Contractor Selection; Performance-based; Analytical Hierarchy Process

\section{Introduction}

Generally, the construction sector can be described as unique and complex as it involves several complex elements such as structure designs, site circumstances, building materials, labour needs, vegetation and paraphernalia necessities, building techniques, practical intricacies, as well as management expertise.

In order to translate design and specifications into reality, the involvement of different parties such as clients, contractors, architects, engineers, approving authorities, suppliers and labours which have their own responsibilities make the process even more complicated (1). Among all the involved parties, contractors have the most important obligation to construct the project within time, budget limits and to comply with the quality according to stakeholder's satisfaction. The project will only to be consider successful if contractor meets those outlined requirements (2).

Of 299 projects which were granted during the $9^{\text {th }}$ and $10^{\text {th }}$ Malaysia Plans, 53.5\% of them experienced delays, as per the Project Management System (SKALA) which was created by the Public Works Department (PWD) with the aim of tracking the progress of projects. Defective planning, substandard management, lack of experience, material and manpower insufficiencies, equipment unavailability and breakdowns, as well as construction errors are the main contractor-related factors which give rise to delays (Sambasivan and Soon (3). Ali, Smith (4) added that in Malaysia, monetary inadequacies of the contractors and faulty works also led to delayed projects.

To ensure successful completion and high standards of the structures, it is important to choose contractors who are financially stable and well-versed in the field (5). Ironically, the bid price is arguably still the main aspect in the process of selecting a contractor although most customers know that the lowest bidder does not necessarily provide good value for money (6).

In Malaysia, delays occur most frequently in the projects which are under the Ministry of Works. Apart from insufficient manpower and skills, the failure of the contractors to adequately plan and schedule the projects also contributes to delays (7). Other causes for the same include contractor insolvency, construction errors, as well as work flaws (4). Evidently, the main contributors to the construction sector in Malaysia are government projects (8). The PWD does not only serve to proffer technical advice; its responsibilities include the development of infrastructure and expansion of the public construction industry as well. Two principal aspects govern the systems by which the PWD appraises tenders and selects contractors, which are financial adequacy as well as technical ability. A study conducted by Jaafar, Abdul Aziz (9) indicated that the former aspect is given much more precedence over the latter in the process of selecting a contractor. This occurrence may explain the declining performance history and work experience of the contractors. Subjective assessments by the clients, apart from inadequate evaluation of the track records, lead to an incomplete weak appraisal of the technical capacities of the contractors. Likewise, the selection process employed by the PWD fails to sufficiently gauge contractors in terms of previous and predicted performances (10). This in turn can give rise to a decrease in the quality of the Malaysian construction industry. 


\section{Literature Review}

The ability to fulfil the targets (i.e. deadlines, expenditure, and quality) of a project defines successful completion of the same (11). Thus, it is important to select a contractor who has the competency to deliver results which are in accordance to the client's expectations. However, as mentioned, the current selection process is marred by non-objective evaluations and inadequate assessments of the contractors' track records. As such, an allinclusive system is warranted in order to make unbiased selections and promote merit-based tendering.

\subsection{Performance-Based Criteria in Contractor Selection}

The aspect which is most predictive of the future performance of the contractors is the assessment of their track records during the selection process (12). Performance indicator has been one of the criteria to determine the success of a construction project. The Rethinking Construction Report established by Egan (13) has outlined three main objectives of key performance indicators (KPIs) which are:-

1. To establish a performance measurement system;

2. To provide methods of comparing the performances of the key players of the construction sector, and;

3. To monitor the patterns of performance over the long run with the intention to determine the fulfilment of the goals laid.

Performance measurement system has been introduced to a large number of companies (14) where the subject covers customer satisfaction, products and services, financial yields, work efficiency, errors, safety, construction duration, as well as expenditure indicators (13).

In line with the construction project success criteria stated earlier, Hatush and Skitmore (15) found that past disappointments, money related status, budgetary solidness, credit ratings, experience, capacity, administrative staff and information will all impact construction execution in terms of time, expense and quality. Furthermore, Alzahrani and Emsley (16) in their research also discovered that turnover history, quality arrangement, work ampleness, plant assets, waste transfer, size of past completed projects and organization image are the most critical variables influencing the project success. Findings by previous researchers have clearly discuss the subject's area to be critically concerned in evaluating tenderers' qualification where these all will affect the project success criteria which are time, quality and construction cost

Providing a benchmark as a method of comparing performance between contractors will definitely help to determine the most eligible contractor for a tendered project. Takim and Akintoye (17) in their findings identified six parameters for benchmarking projects, which are cost of constructions, duration of constructions, predictability of expenditures, forecast ability of time, errors, as well as customer satisfaction.

The most important area contractors need to put high concern are (1) complying with deadlines, (2) creating well-established and trained employees, as well as (3) foster long-term collaborations with sub-contractors (18). Other such aspects include monetary capacity, track record, experience, resources, present job load, previous partnerships, as well as safety handling $(17,19)$. The study conducted by Singh and Tiong (20) described quite a similar contractor selection criteria which further been categorised into five elements which are contracting company's indicators, contractor's past performance, contractor's financial capability, contractor's potential performance and project's specific criteria. Sacks and Harel (21) examined project success as per asset portion by subcontractors over numerous tasks, stated that farfetched arrangements and over commitment responsibilities by subcontractors in various undertakings imperil the connections between the project manager and the subcontractors. The examination prescribed actualizing prequalification criteria to decide potential achievements in projects by thinking about subcontractors conduct crosswise over social, hierarchical and specialized angles. Setting up long term accomplice association with their subcontractors may enhance general execution of the task (18). Apart from performance indicator that also helps augmenting the performance of contractors, Salama, El Aziz (22) reported that the quality of the contractors is a very important performance barometer in the construction sector in Egypt. Yasamis-Speroni, Lee (23) in their study suggests that assessment of contractor's project quality, their specialized ability and monetary solidness may bring about better general capacities of contractors

Considering all the elements and subjects related to be scrutinized on contractor performance, it is essential for them to constantly keep their company records convincing in every aspect. In order to achieve that, Khoshgoftar, Bakar (24) recommend the most crucial things that should be considered by contractors in construction are financial stability, plan and schedule properly, take on projects which are compatible with their experience and potential, make beneficial partnerships with their counterparts, have sufficient paraphernalia and manpower. In addition, emphasising on workers' safety, reliable incorporated documents and integrate previous performance data, solicit client's decisions during contractor prequalification and tender selection processes $(25,26)$.

Mills (27) research concerned identification of pre-qualification aspects which are believed by Australian clients as well as contractors to be reliable predictors of the performance of the construction sector. From here, the five most important factors which were considered to be the most crucial by both parties are previous performance, data on past projects, successful execution of projects, bank references, as well as previous project durations. Others felt that the following should be included in the abovementioned criteria: client satisfaction (28), good track record (29), and resources - which included the on-site employee count (30).

In Malaysia, performance tracking, financial capacity and technical capacity were the most important criteria in selecting main contractors (31). However, the findings only indicate actual client's preference in selecting a contractor, and there is still a need for improvements on current practice in order to have successful completion of construction projects.

Bradshaw and Chang (32) researched into the United States Department of Defence's (DoD) reliance on proposals by contractors during in the process of selecting the latter. It was discovered that inadequate data on previous performance as well as an absence of a proper selection process led to a failure to assess contractor effectively. These data includes the lack of qualifications, contractor dependability, as well as essential workforce, all of which resulted in project delays or failures and over-budgeting.

Risk of reselecting and repeating the same mistake with the same contractor due to the inability to capture the information to prevent it may increase if DoD runs these remedial programs in the absence of well-established procedures and enough data and. While the selection of the most suitable contractors is vital, it is more important to come up with the correct set of parameters as well as predictors. The ideal predictors of contractors' past, current, and future performances are performance indices.

The previous projects undertaken by contractors contribute to their track records. If record is good, then clients will be more likely to be confident with the abilities of the particular contractor.

In Australia, Votano and Sunindijo (33) collected data via questionnaires distributed to the workers of Australian small and medium construction companies. Based on the outcomes, clients are suggested to give precedence to these safety-related measures: (1) take part in on-site safety activities, (2) evaluate and analyse related data, (3) form a team to enforce safety, (4) choose contractors who take safety issues seriously, (5) describe the approaches to safety during tendering, and (6) frequently inspect the premises and paraphernalia. 


\subsection{Performance-Based Criteria Development}

According to Singh and Tiong (34), performance criteria is of two types which are previous performance as well as prospective performance. The former contains several parameters to evaluate the alleged competence of a contractor, while the latter refers to the adequacy of resource and the aptitude of contractors in similar project types.

Based on the performance-based criteria discussed previously, the researcher came up with a summarised performance criteria and some of the sub-criteria has been merged together or separated relevantly.

Table 1: Summarized performance criteria

\begin{tabular}{|l|l|}
\hline Past Performance Criteria & Potential Performance Criteria \\
\hline $\begin{array}{l}\text { Type and scale of project completed } \\
\text { in past 3-5 years }\end{array}$ & $\begin{array}{l}\text { Depth of experience in similar type } \\
\text { of projects }\end{array}$ \\
\hline $\begin{array}{l}\text { Quality of workmanship on past } \\
\text { project }\end{array}$ & $\begin{array}{l}\text { Qualification \& experience of } \\
\text { management staffs }\end{array}$ \\
\hline $\begin{array}{l}\text { Percentage of previous work com- } \\
\text { pleted on schedule 3-5 years }\end{array}$ & $\begin{array}{l}\text { Qualification \& experience of } \\
\text { technical staffs }\end{array}$ \\
\hline $\begin{array}{l}\text { Frequency of previous failure to } \\
\text { perform contract on time or fail to } \\
\text { complete on time }\end{array}$ & Manpower resources \\
\hline $\begin{array}{l}\text { Standard of subcontractors' work } \\
\text { Attitude correcting faulty work }\end{array}$ & $\begin{array}{l}\text { Availability and owned plant and } \\
\text { equipment }\end{array}$ \\
\hline $\begin{array}{l}\text { Relationship with past owner/client } \\
\text { Puality control \& assurance pro- } \\
\text { gram }\end{array}$ \\
\hline $\begin{array}{l}\text { Relationship with past subcontrac- } \\
\text { tors }\end{array}$ & Specialized knowledge \\
\hline Relationship with past suppliers & Quality recognition \\
\hline $\begin{array}{l}\text { Department and/or demerit point of } \\
\text { past project }\end{array}$ & Quality training \\
\hline Customer satisfaction & Safety and Health record \\
\hline
\end{tabular}

\section{Methodology}

This research involved focus group data collection relating preferences on criteria of performance-based tender evaluation. The selection of methodology for Flexible Performance-based Contractor Selection System (FPCSS) relied on professional judgements and expert opinions from practitioners. This research was aiming to develop a FPCSS that incorporates performance indices into the current tender assessment process of the PWD.

Two methods of data gathering that were adopted for this research which were personal interviews and questionnaires survey (a support data collection) for the identification of the would-be parameters to appraise the previous and prospective performances of contractors as well as to grade the importance of individual performance indices. As the nature of this research requires the latest data regarding the happenings in the construction sector, the present tender assessment methods employed by the government, as well as issues related to current practice, thus Quantity Surveyors (QS) who are known to be the experts in tender evaluation and getting involved in the whole process of tendering was selected for research sampling. This study successfully held 6 face-to-face interviews with PWD specialists who were selected through purposive sampling as well as snowballing.

Online questionnaire surveys were distributed to 217 QS's in PWD (46 responses received inclusive of the interviews) to identify performance indicators by level of importance from the perspective of QS in public sector, including PWD. An in-depth interview was later conducted with the main respondent to establish an interviewer-interviewee rapport which would lead to obtaining the detailed as well as precise information needed. When the variety of data exceeded a predetermined threshold, the interviews will be stopped.

Both methods were using Likert scale to explore respondent's preference and by the end of the data gathering process, the scale of the responds in interview and questionnaire surveys were com- bined to determine the mean score of each previous/prospective performance criteria. Lastly, an analytical hierarchy process (AHP) model was devised with respect to the summarised content and statistical analyses of the questionnaires. Here, the average score of individual criterion are coded and their weightage computed.

\subsection{Analytical Hierarchy Process (AHP) Method}

Analytical Hierarchy Process (AHP) method is one of the several approaches exist in selecting the most appropriate contractor, a method used for a multi-criteria decision-making. The researcher made a comparison between existing methods to select the most advantageous method suitable for this study. This method was chosen as it permits subjective and target components to be considered in the multi-criteria assessment process. The advantages of AHP technique is that the subjective judgements and information inconsistencies can be assessed together (35). Furthermore, the researcher found that it is more suitable for the research nature to develop the FPCSS.

As per discussed before, contractors' performance depends on numerous factors, such as subjectivity or objectivity of qualitative evaluation which can be quantitatively calculated from contractors' information (36). Hence, AHP method was selected in this study as it quantifies both non-objective and qualitative data - a property which befits the process of selecting the right contractor. revealed that AHP may help resolve conflicts in judgements and combining different perspectives of decision makers to choose the best alternative.

The researcher discovered several AHP advantages such as it is more convenient and user-friendly, it improves both objectivity and consistency in assignment of weighting factor, it deals with group decision making as well as it reflects the complex reality. However, several disadvantages of this method were identified by which it requires strong assumptions of the interval scale during the calculation of scores, it requires a considerable amount of time to obtain many judgements and the high likelihood of rank reversal. The researcher used AHP method which provides objective evaluations of previous and prospective performance indices, to ensure the integrity as well as originality of the results. It started with the most important step in AHP which is the hierarchical structure by taking into considerations the types of decisions to be made. In this case, selecting a contractor from a list of potential contractors is the overall goal of this structure. The subsequent level comprises the criteria (i.e. previous and potential performance) to be given due consideration to attain the aforementioned objective. This is followed by the sub-criteria for the accomplishment of the key criteria. The alternatives (contractor list) account for the lowermost rank in the hierarchy. Figure 1 shows the analytical hierarchy for FPCSS.

\subsection{Research Ethics, Reliability and Validity}

The researcher has emphasized on ethics, reliability and validity during this study. Consent from respondents has been obtained before collecting data, and the researcher avoids any unethical bias either hiding or highlighting results found as well as properly acknowledging and citing all borrowed ideas from secondary sources. The FPCSS prototype was validated by five experts from PWDs in order to maintain research credibility. This module then sought the opinions of contractors of various ranks as well as grades in order to put the FPCSS into practice. The outcomes of this study contradict those of the literature that utilizes comparative techniques yet diverse unit of investigation to ensure the reliability of findings. 


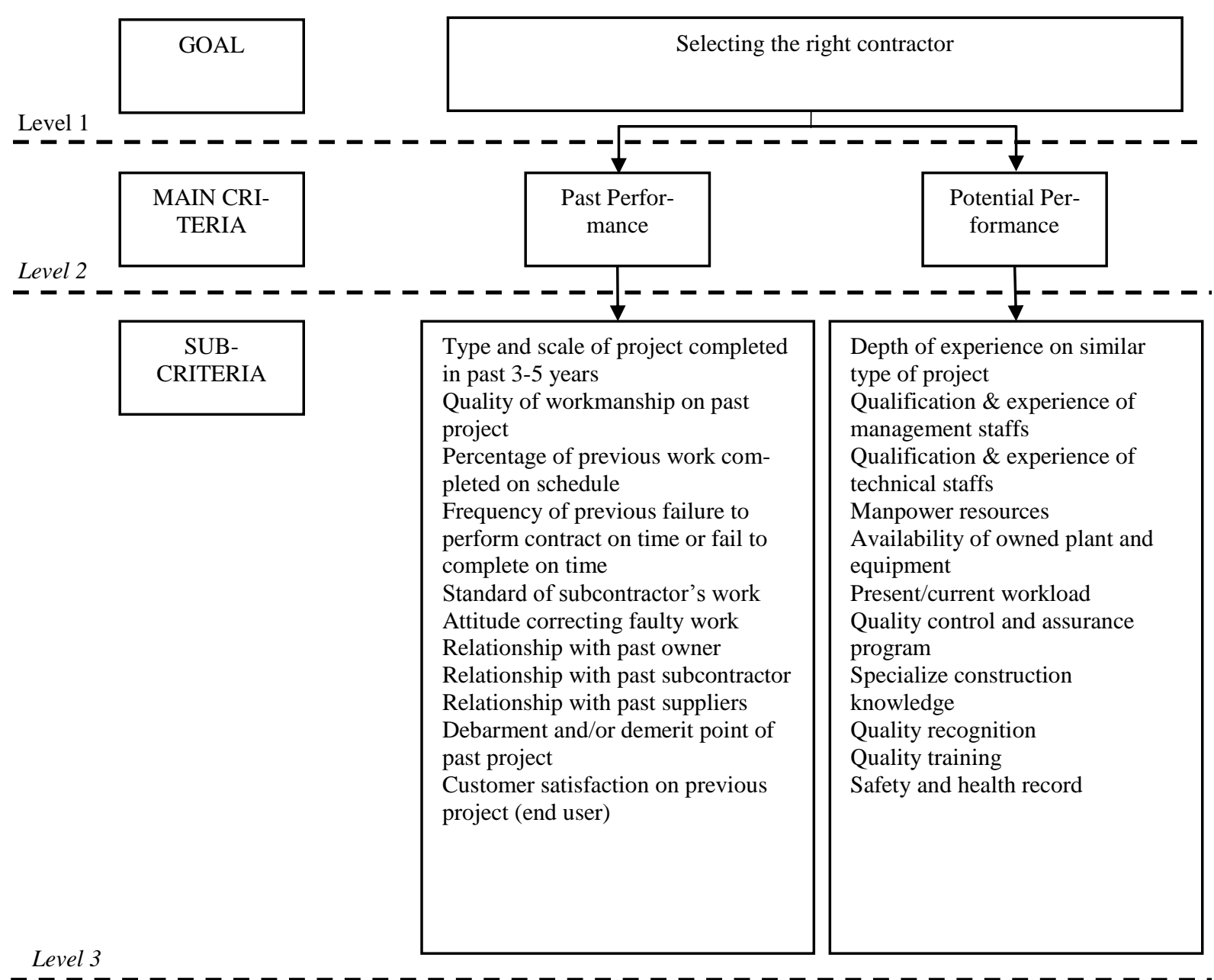

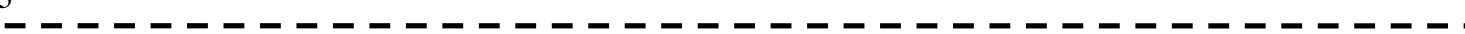

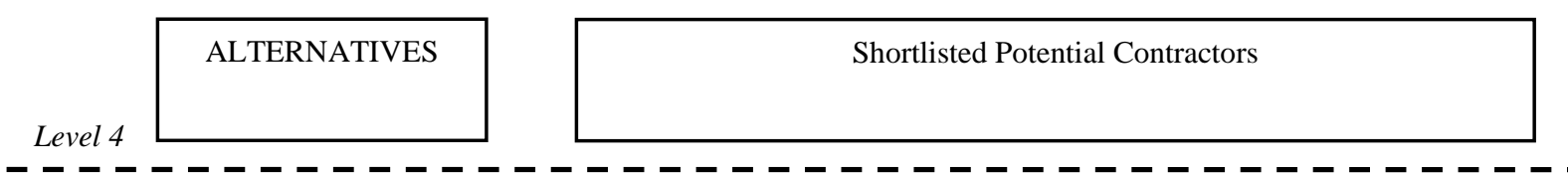

Fig.1: Analytical Hierarchy for FPCSS for contractor selection.

\section{Results and Findings}

\subsection{Past Performance and Potential Performance Weightage}

With a weightage of $20 \%$, the previous project work standard (Pa2) came out top. The inability to execute contracts satisfactorily or comply with the deadlines (Pa4) ranked second. In contrast, subcontractors' quality of work in previous undertakings and good contractor-previous client ties had the least weightage $(2 \%)$ in Previous Performance criteria. Figure below depicts the scores of each Previous Performance sub-criterion:

Table 2: The level of past performance sub-criteria score

\begin{tabular}{|c|c|c|c|c|}
\hline Code & $\begin{array}{l}\text { Past Performance of } \\
\text { contractors }(38)\end{array}$ & Weightage & Percentage & Rank \\
\hline $\mathrm{Pa} 2$ & $\begin{array}{l}\text { Quality of works in past } \\
\text { projects } \quad \text { (QLASSIC } \\
\text { rating) }\end{array}$ & 0.204 & 20 & 1 \\
\hline $\mathrm{Pa} 4$ & $\begin{array}{l}\text { Frequency of previous } \\
\text { failure to perform con- } \\
\text { tracts properly or failure } \\
\text { to comply on time }\end{array}$ & 0.184 & 18 & 2 \\
\hline $\mathrm{Pa} 3$ & $\begin{array}{l}\text { Percentage of previous } \\
\text { works completed on }\end{array}$ & 0.124 & 12 & 3 \\
\hline
\end{tabular}

\begin{tabular}{|c|c|c|c|c|}
\hline Code & $\begin{array}{l}\text { Past Performance of } \\
\text { contractors (38) }\end{array}$ & Weightage & Percentage & Rank \\
\hline & schedule & & & \\
\hline $\mathrm{Pa} 1$ & $\begin{array}{l}\text { Type and scale of pro- } \\
\text { ject completed in past } 3 \text { - } \\
5 \text { years }\end{array}$ & 0.113 & 11 & 4 \\
\hline $\mathrm{Pa} 11$ & $\begin{array}{l}\text { Customer satisfaction on } \\
\text { previous project (end } \\
\text { user) }\end{array}$ & 0.111 & 11 & 5 \\
\hline $\mathrm{Pa} 10$ & $\begin{array}{l}\text { Debarment and/or de- } \\
\text { merit point in past pro- } \\
\text { jects }\end{array}$ & 0.108 & 11 & 6 \\
\hline $\mathrm{Pa} 6$ & $\begin{array}{l}\text { Attitude toward correct- } \\
\text { ing faulty works }\end{array}$ & 0.039 & 4 & 7 \\
\hline $\mathrm{Pa} 9$ & $\begin{array}{l}\text { Relationship with sup- } \\
\text { pliers }\end{array}$ & 0.037 & 4 & 8 \\
\hline $\mathrm{Pa} 8$ & $\begin{array}{l}\text { Relationship with sub- } \\
\text { contractors }\end{array}$ & 0.035 & 4 & 9 \\
\hline $\mathrm{Pa} 7$ & $\begin{array}{l}\text { Good relationship with } \\
\text { past project owners }\end{array}$ & 0.022 & 2 & 10 \\
\hline $\mathrm{Pa} 5$ & $\begin{array}{l}\text { Standard of subcontrac- } \\
\text { tors' works in past pro- } \\
\text { jects }\end{array}$ & 0.022 & 2 & 11 \\
\hline
\end{tabular}

As for the indices of Potential Performance, the factor which had the most weightage $(31 \%)$ was the expertise in related project types (Po1). Labour adequacy (Po4) came in second with a 
weightage of $15 \%$. At the other end of the scale, records on safety and well-being (Po11) contributed the least weightage (1\%).

Table 3: The level of potential performance sub-criteria score

\begin{tabular}{|c|l|c|c|c|}
\hline Code & $\begin{array}{l}\text { Potential Performance } \\
\text { of contractors (8) }\end{array}$ & Weightage & Percentage & Rank \\
\hline Po1 & $\begin{array}{l}\text { Depth of experience on } \\
\text { similar type of projects }\end{array}$ & 0.309 & 31 & 1 \\
\hline Po4 & Manpower resources & 0.148 & 15 & 2 \\
\hline Po3 & $\begin{array}{l}\text { Qualification and experi- } \\
\text { ence of technical staffs }\end{array}$ & 0.140 & 14 & 3 \\
\hline Po6 & $\begin{array}{l}\text { Present workload and } \\
\text { capability to support } \\
\text { current projects }\end{array}$ & 0.137 & 14 & 4 \\
\hline Po8 & $\begin{array}{l}\text { Specialized knowledge } \\
\text { of particular construction } \\
\text { method }\end{array}$ & 0.092 & 9 & 5 \\
\hline Po2 & $\begin{array}{l}\text { Qualification and experi- } \\
\text { ence of management } \\
\text { staffs }\end{array}$ & 0.040 & 4 & 6 \\
\hline Po9 & Quality recognition & 0.038 & 4 & 7 \\
\hline Po7 & $\begin{array}{l}\text { Quality control and as- } \\
\text { surance program }\end{array}$ & 0.037 & 4 & 8 \\
\hline Po5 & $\begin{array}{l}\text { Availability of owned } \\
\text { construction plant and } \\
\text { equipment }\end{array}$ & 0.024 & 2 & 9 \\
\hline Po10 & Quality training & 0.023 & 2 & 10 \\
\hline Po11 & Safety and Health record & 0.013 & 1 & 11 \\
\hline
\end{tabular}

\subsection{FPCSS Development}

The FPCSS prototype has been devised by means of identifying the most relevant criteria as well as sub-criteria in the process of coming up with an outline for the process of choosing contractors. This has also been further validated by the subject experts which were contractors. The experts' task was to validate the module and prototype whilst contractors to provide their perspective on the FPCSS prototype. Figure 2 below shows the flowchart of FPCSS procedure.

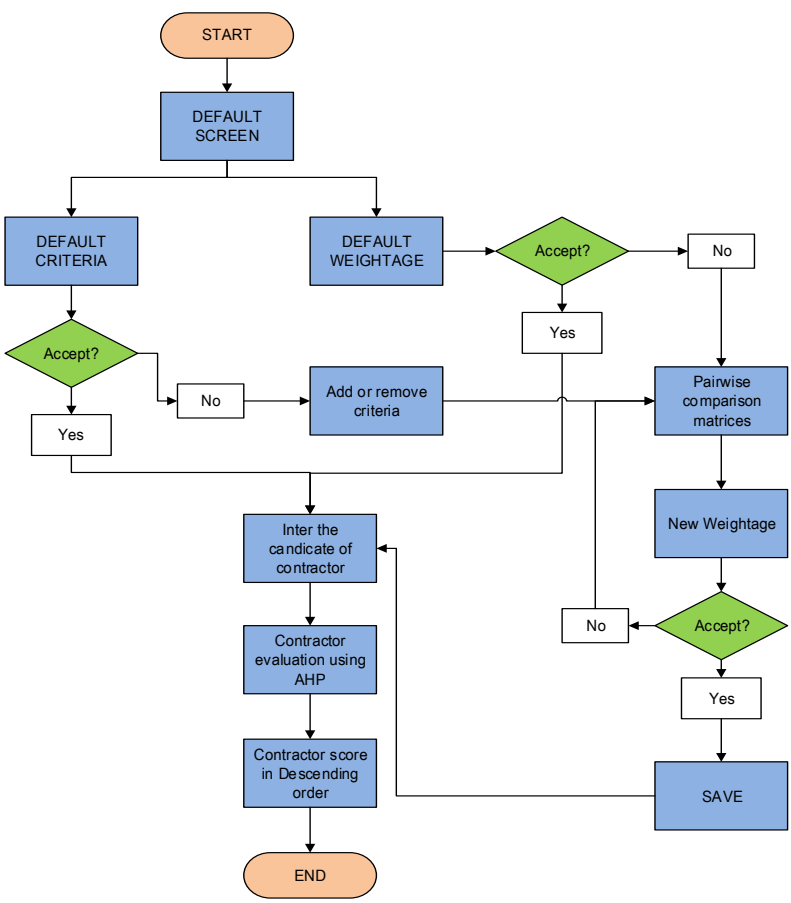

Fig. 2: Flowchart of FPCSS

The average scores for each of previous and potential performance were generated after clicking the "submit" button. After evaluating the performance of contractors, the scores for both categories were computed accordingly and displayed on the toolbar menu (see figure 3 and 4 below). Subsequently, the average score for both categories were merged to give a comprehensive idea of contractors' performance. Lastly, a final score was calculated by averaging those for performance indices and financial ability, after which it is utilised in the project-awarding exercise.

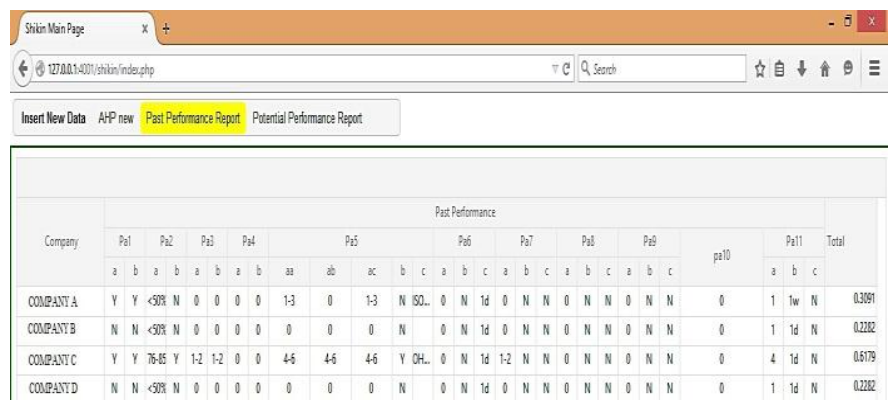

Fig. 3: Past performance score result

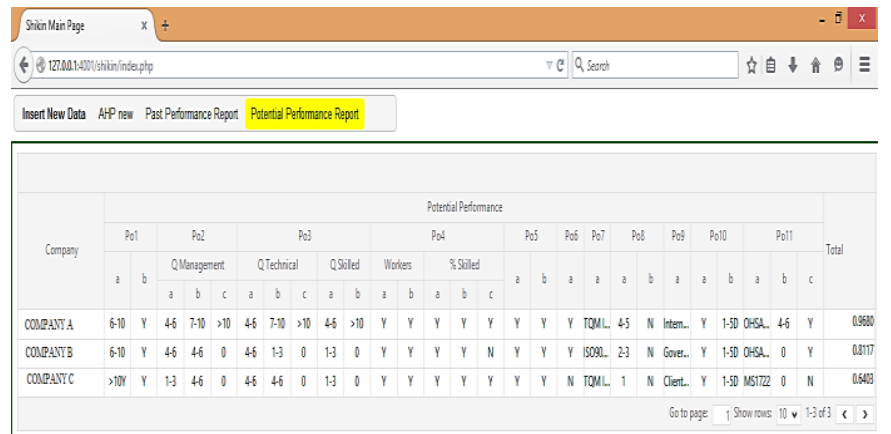

Fig. 4: Potential performance score result

\subsection{FPCSS Prototype Result Discussion}

The proposed FPCSS process is produced to pick the most suitable contractors amid tender assessment.

Experts were asked regarding their assent to the implementation of this model and their comments obtained:-

i. All of them concurred that the aforementioned model befitted the purpose of FPCSS.

ii. It was verified that the outcomes as well as flowcharts of the model were valid, and that no activities had been left out.

iii. The contents of the FPCSS have fulfilled all the objectives of choosing the highest-performing contractors who are most suited for a particular project.

iv. In order to procure the details needed to assess individual performance indices, a standard form needs to be created.

v. FPCSS can be practically implemented.

Even though this model was devised with respect to the PWD's inclinations and priorities in the process of choosing the most suitable contractor, it is still important to seek feedback from contractors on the performance indices that were utilised so as to select eligible contractors for a project. The advantages of this model were agreed upon by the majority of respondents. Some of the feedbacks on advantages and disadvantages of this model is listed in Table 4 below.

Table 2: Feedbacks on advantages and disadvantages of the model

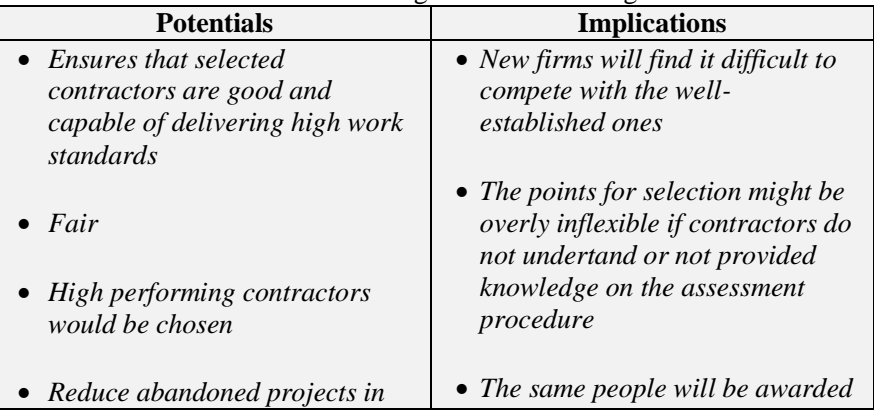




\begin{tabular}{|c|c|}
\hline $\begin{array}{l}\text { Malaysia } \\
\text { - Predict project performance } \\
\text { - Financials and work quality are } \\
\text { vital in assessing performances } \\
\text { of contractors } \\
\text { - Reassurance from government } \\
\text { that experienced contractors are } \\
\text { executing the project } \\
\text { - Promotes unbiased assessments } \\
\text { of tenders } \\
\text { - Highly-experienced contractors } \\
\text { fulfill customers' requirements } \\
\text { in projects e.g. specialised } \\
\text { works } \\
\text { - Augment contractors job } \\
\text { standards } \\
\text { - Encourages professional } \\
\text { attitudes and avoids license } \\
\text { misuse } \\
\text { - Minimises failures in } \\
\text { subsequent projects }\end{array}$ & $\begin{array}{l}\text { tenders every time } \\
\text { - New, inexperienced contractors } \\
\text { would face difficulty in securing } \\
\text { jobs } \\
\text { - Too subjective }\end{array}$ \\
\hline
\end{tabular}

Most participants in this study concurred that the pros outweigh the cons of this model. Respondents were asked about the feasibility of the implementation of the same in the construction sector, to which most of them gave positive feedbacks to the prototype system, hence indicating its reliability. Feedbacks from respondents regarding agreement of FPCSS can be referred to Table 5.

Table 3: Feedbacks from respondents regarding agreement of FPCSS

\begin{tabular}{|c|l|}
\hline No. & Responses of positive reasons from respondents \\
\hline i. & It promotes integrity among Malaysian contractors \\
\hline ii. & $\begin{array}{l}\text { Nowadays, contractors focus on getting the project instead of } \\
\text { studying or understanding the details of the same. With this } \\
\text { FPCSS, the tender evaluation procedure will predominantly } \\
\text { take into account the track records and experience to prevent } \\
\text { conflicts arising after the commencement of projects. Con- } \\
\text { tractors must be specialized in the type of construction that } \\
\text { they are doing (except for just a conventional elementary } \\
\text { structure) }\end{array}$ \\
\hline iii. & $\begin{array}{l}\text { The government can plainly and easily implement FPCSS in } \\
\text { all assessment methods }\end{array}$ \\
\hline iv. & $\begin{array}{l}\text { To give opportunities to good contractors, which in turn } \\
\text { improves the quality of the Malaysian construction sector via } \\
\text { delivery of high-standard outcomes }\end{array}$ \\
\hline v. & $\begin{array}{l}\text { This model is feasible, but its implementation should be } \\
\text { gradual, with trainings and seminars for contractors regarding } \\
\text { the same }\end{array}$ \\
\hline vi. & For healthy competition \\
\hline vii. & $\begin{array}{l}\text { Projects need to be awarded to high performing contractors } \\
\text { instead of those with good connections with politicians }\end{array}$ \\
\hline viii. & $\begin{array}{l}\text { While the model is not 100\% valid, it can facilitate the timely } \\
\text { completion and good condition of projects }\end{array}$ \\
\hline ix. & $\begin{array}{l}\text { An additional point is that the tender should clearly stipulate } \\
\text { the estimated expenditure, something which is currently } \\
\text { practised by the PWD }\end{array}$ \\
\hline x. & Contractors will strive to improve themselves \\
This model is good \\
\hline
\end{tabular}

\subsection{Discussion}

FPCSS established to objectively determine the contractors' performances to facilitate the selection of the most suitable contractors. Past and Potential performances are the two principal criteria of the system. From here, there are 22 sub-criteria; 11 for each principal criterion. These main criteria and sub-criteria were iden- tified from past studies as well as literature evaluations. Interviews and surveys were conducted to assign a specific weightage to each sub-criterion.

The AHP method was employed to objectively assess the integrity as well as originality of the aforementioned system. The current tendering process utilised by the PWD subjectively appraises the track records of the contractors. As such, the said method converts the vagueness of the selection process to a few empirical parameters which are organised in a hierarchical manner, the latter of which allows objective measurements. The weightage developed for this model has been set as default weightage for performancebased evaluation to select contractor. However, the users may modify the criteria and the weightage according to any project objective. It is a flexible decision-making model that concurs with the attitudes of the behaviour of the clients as they tend to come up with decisions based on their experience as well as knowledge. The current tendering process adopted by the PWD comprises two chief aspects: monetary as well as technical. The PWD employs objective measurements of the financial ability of the contractors owing to the availability of this information. However, the fairness of the method of evaluating the technical factors (i.e. past experience of the contractors, plant, equipment, as well as technical employees) has frequently been questioned as it is executed nonobjectively. Therefore, the technical capability criteria has been identified by the respondents as the weakest part of the system. According to the content analysis, the FPCSS replaces the technical aspects in the existing system. This amalgamation is mainly aimed to rectify the weaknesses of the current system, but not amounting to completely altering the same. In other words, the model complements the present system, apart from increasing the reliability of the assessments in selecting the most suitable contractors.

Validations were performed on the module as well as draft so as to ascertain the data's correctness, apart from improving the current practices. A summary of the experts' feedback are as follows: (1) the module serves the purpose of the merit-based contractor selection process, (2) the outcomes as well as flowcharts of the model were valid, and that no activities had been left out, (3) The contents of the FPCSS have fulfilled all the objectives of choosing the highest-performing contractors who are most suited for a particular project, (4) a standardised form is required for obtaining the details needed to assess individual performance criteria, as well as (5) the FPCSS is feasible for implementation.

To conclude, the majority of the participants concurred that the strengths outweigh the downsides of this model, and gave positive responses to the FPCSS. It was also believed that implementing this FPCSS will make the tender assessment procedure a transparent one. An indirect effect of this scenario is that contractors will be motivated to enhance their subsequent delivery of outcomes.

\section{Conclusion}

The merit-based assessment system aims to appraise contractors in terms of their previous as well as prospective performances, apart from facilitating the use of empirical assessment methods. It must be noted that the aforementioned system merely complements the current PWD tender assessment practices rather than changing it entirely. This research contributed some extra information to upgrade the presently-available literature regarding construction, and new knowledge regarding the FPCSS for contractor selection could give impact for the construction parties such as clients and contractor as well as to the industry itself. Future research is recommended to investigate how applicable the FPCSS is to other Asia countries such as Indonesia, Thailand and Vietnam and etc. 


\section{Acknowledgement}

This research work is supported by the Public Work Department of Malaysia.

\section{References}

[1] Haseeb M, Bibi A, Rabbani W. Problems of projects and effects of delays in the construction industry of Pakistan. Australian journal of business and management research. 2011;1(6):41.

[2] Abedi M, Fathi M, Mohammad M. Effects of construction delays on construction project objectives. 2011

[3] Sambasivan M, Soon YW. Causes and effects of delays in Malaysian construction industry. International Journal of project management. 2007;25(5):517-26

[4] Ali AS, Smith A, Pitt M. Contractors' perception of factors contributing to project delay: case studies of commercial projects in Klang Valley, Malaysia. Journal of Design and Built Environment. 2012;7(1).

[5] Ergonul S, Yilmaz A. Selection of contractors for middle-sized projects in Turkey. Gazi University Journal of Science. 2011;24(3):477-85.

[6] Xu J, Liu YX, Luo LF. A trust-based method in construction industry. Applied Mechanics and Materials. 2014;539:762.

[7] Abdul-Rahman H, Berawi M, Berawi A, Mohamed O, Othman M Yahya I. Delay mitigation in the Malaysian construction industry. Journal of construction engineering and management 2006;132(2):125-33.

[8] Ramanathan C, Potty NS, Idrus AB, editors. Analysis of time and cost overrun in Malaysian construction. Advanced Materials Research; 2012: Trans Tech Publ.

[9] Jaafar M, Abdul Aziz A, Ismail A, editors. Non Price Factor (NPF) and contractors' selection: An application in the Public Sector Malaysia. Proceeding of 5th IEEE International Conference of Cognitive Informatics; 2006.

[10] Ariffin Z. Public Work Department tender evaluation system. In: Shukery NM, editor. 2014.

[11] Cooke-Davies T. The "real" success factors on projects. International journal of project management. 2002;20(3):185-90.

[12] El-Sawalhi N, Eaton D, Rustom R. Contractor pre-qualification model: State-of-the-art. International Journal of Project Management. 2007;25(5):465-74.

[13] Egan J. Rethink Construction. The Construction Task Force Department of the Environment, Transport and the Regions, London. 1998.

[14] Beatham S, Anumba C, Thorpe T, Hedges I. KPIs: a critical appraisal of their use in construction. Benchmarking: An International Journal. 2004;11(1):93-117.

[15] Hatush Z, Skitmore M. Criteria for contractor selection Construction Management \& Economics. 1997;15(1):19-38

[16] Alzahrani JI, Emsley MW. The impact of contractors' attributes on construction project success: A post construction evaluation International Journal of Project Management. 2013;31(2):313-22.

[17] Takim R, Akintoye A, editors. A conceptual model for successfu construction project performance. In: Greenwood, D (Ed), 18th Annual ARCOM Conference, 2-4 September 2002, University of Northumbria Association of Researchers in Construction Management; 2002: Citeseer.

[18] Xiao H, Proverbs D. Factors influencing contractor performance: an international investigation. Engineering, Construction and Architectural Management. 2003;10(5):322-32

[19] Cheng EW, Li H. Contractor selection using the analytic network process. Construction management and Economics. 2004;22(10):1021-32.

[20] Singh D, Tiong RL. A fuzzy decision framework for contractor selection. Journal of Construction Engineering and Management. 2005;131(1):62-70.

[21] Sacks R, Harel M. An economic game theory model of subcontractor resource allocation behaviour. Construction Management and Economics. 2006;24(8):869-81.

[22] Salama M, El Aziz HA, El Sawah H, El Samadony A. Investigating the criteria for contractors' selection and bid evaluation in Egypt. Management. 2006;531:540.

[23] Yasamis-Speroni F, Lee D-E, Arditi D. Evaluating the quality performance of pavement contractors. Journal of Construction Engineering and Management. 2012;138(10):1114-24.
[24] Khoshgoftar M, Bakar AHA, Osman O. Causes of delays in Iranian construction projects. International Journal of Construction Management. 2010;10(2):53-69.

[25] Tao L, Kumaraswamy M. Unveiling relationships between contractor inputs and performance outputs. Construction Innovation. 2012;12(1):86-98.

[26] Toor S-u-R, Ogunlana SO. Beyond the 'iron triangle': Stakeholder perception of key performance indicators (KPIs) for large-scale public sector development projects. International journal of project management. 2010;28(3):228-36.

[27] Mills AJ. The impact of client attitudes on the selection of contractors. Malaysian construction research journal. 2011;8(1):88102.

[28] Yang J-B, Peng S-C. Development of a customer satisfaction evaluation model for construction project management. Building and Environment. 2008;43(4):458-68.

[29] Yasamis F, Arditi D, Mohammadi J. Assessing contractor quality performance. Construction Management \& Economics. 2002;20(3):211-23.

[30] Florez L, Castro D, Medaglia AL, editors. Maximizing labor stability as a sustainability performance indicator in project scheduling. Construction Research Congress 2012: Construction Challenges in a Flat World; 2012.

[31] Idrus A, Sodangi M, Amran MA. Decision criteria for selecting main contractors in Malaysia. Research Journal of Applied Sciences, Engineering and Technology. 2011;3(12):1358-65.

[32] Bradshaw J, Chang S. Past performance as an indicator of future performance: selecting an industry partner to maximize the probability of program success. Defense AR Journal. 2013;20(1):59-80.

[33] Votano S, Sunindijo RY. Client safety roles in small and medium construction projects in Australia. Journal of Construction Engineering and Management. 2014;140(9):04014045.

[34] Singh D, Tiong RL. Contractor selection criteria: investigation of opinions of Singapore construction practitioners. Journal of construction engineering and management. 2006;132(9):998-1008.

[35] Hosny O, Nassar K, Esmail Y. Prequalification of Egyptian construction contractors using fuzzy-AHP models. Engineering, Construction and Architectural Management. 2013;20(4):381-405.

[36] Nassar K, Hosny O. Fuzzy clustering validity for contractor performance evaluation: Application to UAE contractors. Automation in Construction. 2013;31:158-68.

[37] Perera N, Sutrisna M. The use of analytic hierarchy process (AHP) in the analysis of delay claims in construction projects in the UAE. The Built \& Human Environment Review. 2010;3(1):29-48.

[38] Department PW. Project Management System. 2014. 